\title{
Experimental Study of Use of Ionic Liquids in Enhanced Oil Recovery
}

\author{
Mabkhot S Bin-Dahbag ${ }^{1 *}$, Abdulrahman A Al Quraishi ${ }^{2}$, Mohammed S Benzagouta ${ }^{1}$, Mustafa M Kinawy ${ }^{1}$, Inas M Al Nashef ${ }^{3}$ and Emad Al \\ Mushaegeh $^{2}$
}

${ }^{1}$ Department of Petroleum and Natural Gas Engineering, King Saud University, Saudi Arabia

${ }^{2}$ Oil and Gas Research Institute, King Abdulaziz City for Sciences and Technology, Saudi Arabia

${ }^{3}$ Department of Chemical Engineering, King Saud University, Saudi Arabia

\begin{abstract}
Chemical flooding process has shown great potential in Enhanced Oil Recovery (EOR). Unfortunately, chemicals used have some disadvantages such as high cost, high toxicity and high adsorption tendency. In this study, we aim at using lonic Liquids (ILs) as alternatives for traditional chemicals. lonic liquids are salts having melting point below $100^{\circ} \mathrm{C}$ and they found as a liquid at room temperature.

Nine Ammonium and Phosphonium based ILs were screened. The screening was based on their solubility in brines of different compositions, thermal stability and ability to reduce the aqueous-oleic phase's Interfacial Tension (IFT). The screening process flagged Ammoeng 102 as the favored ionic liquid. More investigations of Ammoeng 102 solutions indicated a sharp exponential decrease of IFT values with increasing concentration. On contrary to surfactant solutions, Lower IFT values were obtained with increasing brine salinity indicating the ILs superiority in high salinity reservoirs.

Two tertiary flooding experiments were conducted using 500 ppm Ammoeng 102 diluted in $10 \%$ and $20 \%$ (w/w) brine salinity to investigate its recovery efficiency. Lower salinity secondary brine flooding provided higher recovery. The opposite trend occurred in tertiary ionic solution flooding where recovery is higher for high salinity ionic solution indicating the effectiveness of ILs in recovering oil in high salinity, high temperature environment. In addition, the low cost and low toxicity are more advantages to promote the use of lonic liquids in future EOR processes.
\end{abstract}

Keywords: Ammonium; Phosphonium; Surfactant solutions; Enhanced oil recovery

\section{Introduction}

Ionic liquids, known as salts having a melting point below $100^{\circ} \mathrm{C}$, have recently attracted considerable attention as potential alternatives to conventional organic solvents. ILs consist typically of organic cations such as imidazolium, or pyridinium cation and inorganic anions such as halide, $\left.[\mathrm{AlCl} 4]^{-},{ }^{\mathrm{BF}} 4\right]^{-}$, or $[\mathrm{PF} 6]^{-}$and are very often found as liquids at room temperature $[1,2]$. There are many types of ILs but the most common types are cation organic ILs, anion organic ILs and anion inorganic ILs.

ILs are characterized by properties such as negligible vapor pressure and non-flammability under ambient conditions, high thermal conductivity, high polarity, high heat capacity, high density, extremely low volatility and high thermal stability $[1,3,4]$. Itis known for itlow cost and commercial availability, water stability, low toxicity, low environmental impact, noncorrosive properties, and recyclability. However, the most important attribute of ILs is the possibility of designing their properties based on the number of cations and anions combination $[1,5]$.

Owing to difficulties in producing large amount of crude oil by traditional methods, enhanced oil recovery techniques have been developed. Surfactant flooding is one of the methods used in this regard. This process is intended to decrease Interfacial Tension (IFT) between injected brine and resident crude oil and/or alter rock wetting properties. Some disadvantages that limit the implementation of surfactant flooding are the chemicals high cost, high toxicity, and reservoir damage due to chemicals adsorption on rock grain surfaces. Several studies were conducted to investigate the effect of ILs on interfacial tension and its favorable impact on production [6-8]. ILs can lower the interfacial tension effectively; hence, it can replace the conventional chemicals such as solvents or co-solvents that are known for their toxicity in addition to their high cost compared to ILs.

The anticipated potential of ILs in Enhanced Oil Recovery (EOR) process and the lack of deep research work propped us to investigate ILs as future EOR chemicals. The work was started by screening different ILs to determine the most effective one for our application. Different factors were investigated and among these factors are aqueous phase composition and salinity, ILs concentration, and testing conditions of temperature and pressure. The most efficient IL was tested further and its feasibility as flooding chemical was investigated on Berea sandstone core samples at reservoir conditions of pressure and temperature.

\section{Material}

Many commercialAmmonium and Phosphonium based ionic liquids were screened. Distilled water and three types of brines composed of sodium chloride $(\mathrm{NaCl})$ and calcium chloride $\left(\mathrm{CaCl}_{2}\right)$ dissolved in distilled water at $10 \%$ salinity $(\mathrm{w} / \mathrm{w})$ were used as aqueous phases in screening process. These brines are: Brine I $(100 \% \mathrm{NaCl})$,

*Corresponding author: Mabkhot S Bin-Dahbag, Department of Petroleum and Natural Gas Engineering, King Saud University, Saudi Arabia, Tel: 966556019372; E-mail: en.mabkhot@gmail.com

Received December 01, 2013; Accepted December 27, 2013; Published January 03, 2014

Citation: Bin-Dahbag MS, Quraishi AAAI, Benzagouta MS, Kinawy MM, Nashef IMAI, et al. (2014) Experimental Study of Use of Ionic Liquids in Enhanced Oil Recovery. J Pet Environ Biotechnol 4: 165. doi:10.4172/2157-7463.1000165

Copyright: (C) 2014 SBin-Dahbag MS, et al. This is an open-access article distributed under the terms of the Creative Commons Attribution License, which permits unrestricted use, distribution, and reproduction in any medium, provided the original author and source are credited. 
Citation: Bin-Dahbag MS, Quraishi AAAl, Benzagouta MS, Kinawy MM, Nashef IMAI, et al. (2014) Experimental Study of Use of lonic Liquids in Enhanced Oil Recovery. J Pet Environ Biotechnol 4: 165. doi:10.4172/2157-7463.1000165

Page 2 of 7

Brine II (95\% $\mathrm{NaCl}$ and $\left.5 \% \mathrm{CaCl}_{2}\right)$, Brine III ( $83 \% \mathrm{NaCl}$ and $\left.17 \% \mathrm{CaCl}_{2}\right)$. The oleic phase was Saudi medium crude oil. Brine III at $10 \%$ and $20 \%$ salinity $(w / w)$ was used as aqueous phase in further investigation of the chosen ionic liquid. Table 1 lists the physical properties of oleic phase and aqueous phase (Brine III) at $10 \%$ and $20 \%(\mathrm{w} / \mathrm{w})$ salinity measured at reservoir conditions of $2000 \mathrm{psig}$ and $60^{\circ} \mathrm{C}$. Three homogenous Berea sandstone rock samples from same block were used as porous medium in the flooding runs. XRD analysis (Figure 1) showed that samples are mostly composed of Quartz with small amount of Kaolinite as cementing material. Table 2 summarizes rock samples petrophysical properties.

\section{Experimental Work}

Interfacial Tension (IFT) between oleic and aqueous phases was measured using pendant drop tensiometer (Figure 2). This device measures IFT based on Young-Laplace equation. The high pressure cell is first filled with the aqueous phase and pressure is increased to the desired level. Temperature is set to the desired value and we wait for temperature to stabilize. A needle is raised in the pressure cell and a sufficient drop size of oleic phase is injected. A digital image of the drop is made and transferred to the software where IFT is measured. Several measurements were made and an average IFT value is taken.

Flooding runs were performed using automated core flooding unit shown in Figure 3. Experiments were conducted at reservoir conditions of 5000 psig confining pressure, 2000 psig pore pressure and $60^{\circ} \mathrm{C}$ temperature. Each test started by saturating core samples under vacuum with free air brine solution. Saturated sample was placed in core holder and reservoir conditions were applied. Synthetic

\begin{tabular}{|l|l|c|c|}
\hline Phase & Fluid Type & Viscosity(cp) & Density $\left(\mathbf{g m} / \mathbf{c m}^{3}\right)$ \\
\hline Aqueous & $\begin{array}{l}10 \% \text { salinity Bine III }(83 \% \mathrm{NaCl} \\
\left.\text { and } 17 \% \mathrm{CaCl}_{2}\right)\end{array}$ & 0.8104 & 1.07101 \\
\hline & $\begin{array}{l}20 \% \text { salinity brine III }(83 \% \mathrm{NaCl} \\
\left.\text { and } 17 \% \mathrm{CaCl}_{2}\right)\end{array}$ & 1.0125 & 1.15096 \\
\hline Oleic & Medium Crude Oil & 5.5 & 0.88289 \\
\hline
\end{tabular}

Table 1: Fluid Physical Propertiesat 2000 psig and $60^{\circ} \mathrm{C}$

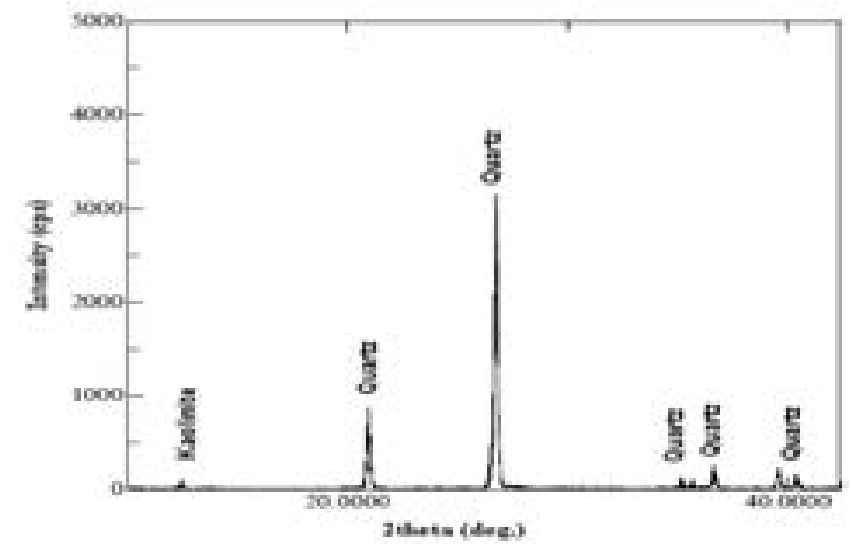

Figure 1: XRD Analysis for Berea Sandstone Core Sample.

\begin{tabular}{|c|c|c|c|c|}
\hline Run No. & $\begin{array}{c}\text { Diameter } \\
\text { (cm) }\end{array}$ & $\begin{array}{c}\text { Length } \\
\text { (cm) }\end{array}$ & $\begin{array}{c}\text { Porosity } \\
\text { (\%) }\end{array}$ & $\begin{array}{c}\text { Absolute Permeability } \\
\text { (md) }\end{array}$ \\
\hline 1 & 3.7 & 7.46 & 22 & 244 \\
\hline 2 & 3.72 & 7.29 & 22 & 263 \\
\hline 3 & 3.72 & 7.11 & 21.5 & 231 \\
\hline \multicolumn{5}{|c}{ Table 2: Rock Physical Properties. }
\end{tabular}

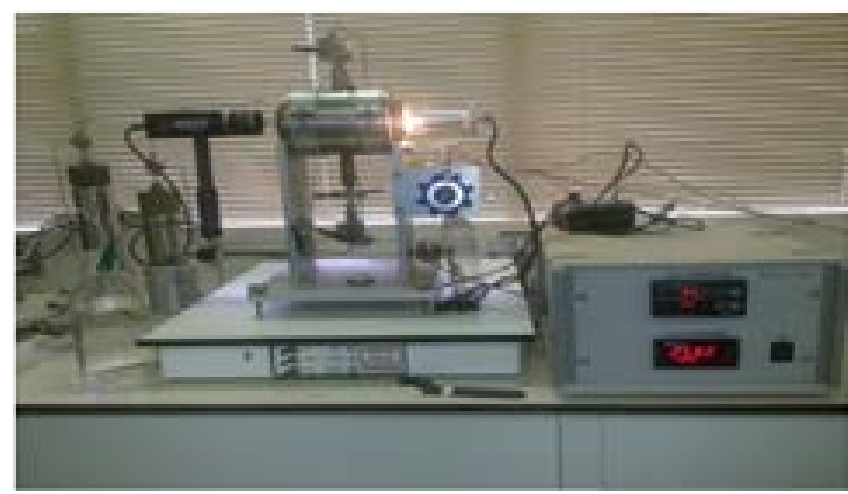

Figure 2: Pendant Drop Tensiometer.

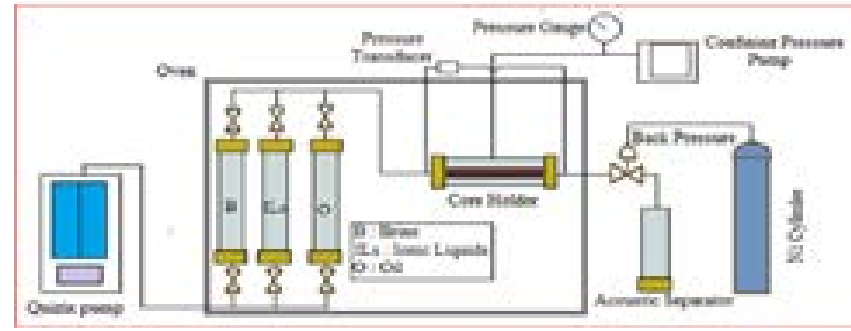

Figure 3: Schematic of Core Flooding Unit.

formation brine was injected through the core sample at different flow rates and absolute permeability was calculated using Darcy law. The fully saturated core was flooded with crude oil at $1 \mathrm{~cm}^{3} / \mathrm{min}$. Flooding continued until water production ceases. Irreducible water saturation $\left(\mathrm{Sw}_{\mathrm{irr}}\right)$ and initial oil saturation were calculated using material balance. Steady state pressure drop was measured to calculate crude oil effective permeability using Darcy law. The core sample was then flooded with brine at $1 \mathrm{~cm} 3 / \mathrm{min}$. The flooding process continued until oil production ceases. Effluents were collected in acoustic separator and oil recovery curve and core fluids saturations were calculated using material balance equation. Tertiary flooding was started at residual oil saturation with selected ionic solution and extra oil recovery was measured.

\section{Results and Discussion}

\section{Screening process}

Nine Ammonium and Phosphonium based ILs were screened. Screening process was based on ILs solubility in brines (I, II, III) and distilled water, thermal stability (no turbidity) and their effectiveness in lowering aqueous-oleic phases IFT at different temperatures ranging from 22 to $90^{\circ} \mathrm{C}$ and atmospheric pressure. IFT measurements were conducted at ILs concentrations ranging from 100 to $1000 \mathrm{ppm}$ diluted in distilled water and brines I, II, III. All brine solutions were prepared at $10 \% \mathrm{w} / \mathrm{w}$ salinity. Table 3 summarizes the ILs screened and the observations obtained at the corresponding conditions. All investigated ILs are soluble in brine and thermally stable at temperature below $80^{\circ} \mathrm{C}$ except the Ammoeng 130 and IL7. However, in contrast to other ILs, Ammoeng 102 was the only IL soluble in all aqueous phases tested with significant ability to lower IFT at increasing temperatures. Figure 4 illustrates the thermal stability of Ammoeng 102 up to $80^{\circ} \mathrm{C}$. Turbidity starts at $82^{\circ} \mathrm{C}$ and at $86^{\circ} \mathrm{C}$ tensiometer was not able to do the measurement. Figure 5 plots the IFT measurements at of all ILs at 
Citation: Bin-Dahbag MS, Quraishi AAAI, Benzagouta MS, Kinawy MM, Nashef IMAI, et al. (2014) Experimental Study of Use of lonic Liquids in Enhanced Oil Recovery. J Pet Environ Biotechnol 4: 165. doi:10.4172/2157-7463.1000165

Page 3 of 7

\begin{tabular}{|c|c|c|c|c|c|}
\hline No. & Name & Base Type & Solubility & IFT Trend With Temperature & Temperature Stability \\
\hline 1 & Ammoeng 102 & Ammonium & $\begin{array}{l}\text { Soluble in distilled water, } \\
\text { brine I, II, III }\end{array}$ & Decreasing & $\begin{array}{l}\text { Stable until } 80^{\circ} \mathrm{C} \text { in all brines and distillated water. } \\
\text { IFT is very low. }\end{array}$ \\
\hline 2 & Ammoeng 112 & Ammonium & Not soluble in brine III & Increasing & Stable until $90^{\circ}$ in brine (I).However, IFT is very high \\
\hline 3 & Ammoeng 120 & Ammonium & $\begin{array}{l}\text { Soluble in distilled water, } \\
\text { brine I }\end{array}$ & Increasing & $\begin{array}{l}\text { Stable until } 90^{\circ} \text { in distillatedwater and brine }(\mathrm{I}) \\
\text { However, IFT is very high }\end{array}$ \\
\hline 4 & Ammoeng 130 & Ammonium & $\begin{array}{l}\text { Not soluble in distilled water } \\
\text { and brines }\end{array}$ & $\begin{array}{l}\text { Unable to measure because IL is } \\
\text { not soluble }\end{array}$ & Unable to measure because IL is not soluble \\
\hline 5 & IL6 & Phosphonium & $\begin{array}{l}\text { Soluble in distilled water, } \\
\text { brine III }\end{array}$ & Decreasing & Stable until $90^{\circ} \mathrm{C}$ in brine (III). However, IFT is very high \\
\hline 6 & IL7 & Phosphonium & Not soluble in all brines & $\begin{array}{l}\text { Unable to measure because IL is } \\
\text { not soluble }\end{array}$ & Unable to measure because IL is not soluble \\
\hline 7 & IL25 & Phosphonium & Soluble in distilled water & Increasing & Stable until $90^{\circ} \mathrm{C}$ in brine (III). However, IFT is Very high. \\
\hline 8 & IL34 & Phosphonium & $\begin{array}{l}\text { Soluble in distilled water, } \\
\text { brine III }\end{array}$ & Increasing & Stable until $90^{\circ} \mathrm{C}$ in brine (III). However, IFT is very high \\
\hline 9 & IL37 & Phosphonium & Soluble in Brine I & Increasing & Stable until $80^{\circ} \mathrm{C}$ in brine (I). However, IFT is very high. \\
\hline
\end{tabular}

Table 3: Summary of lonic Liquids Screening Results.

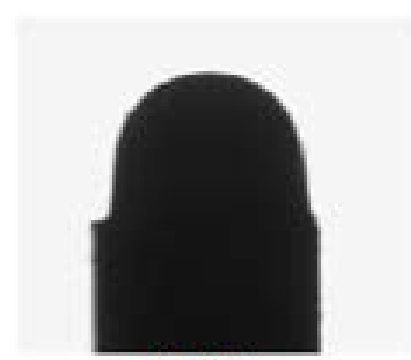

$81^{\circ} \mathrm{C}$

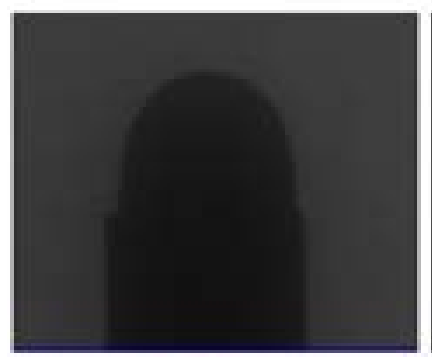

$84^{\circ} \mathrm{C}$

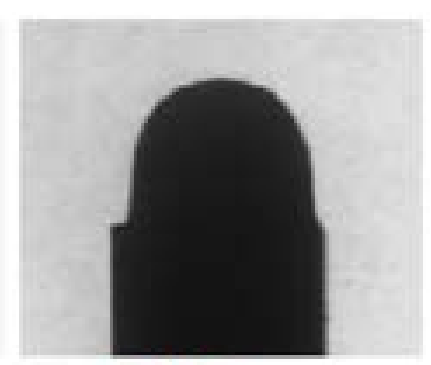

$82^{\circ} \mathrm{C}$

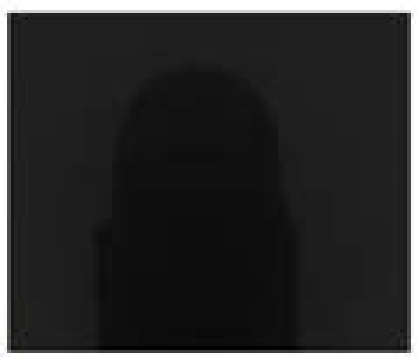

$86^{\circ} \mathrm{C}$
Figure 4: Torbidity of Ammoeng 102 Diluted in Brine III at 10\% (w/w) Salinity.

different temperatures, and IL concentrations. Based on the screening process, Ammoeng 102 was chosen for further investigation.

Critical Micelle Concentration (CMC) is the concentration at which IL solutions begin to form micelles at large amount and the IFT is not reduced anymore as the IL concentrations increases. In order to find the CMC of the Ammoeng 102 solution, the IFT of crude oil-ionic solution at different concentrations were measured at reservoir conditions of 2000 psig and $60^{\circ} \mathrm{C}$.Ammoeng 102 solutions were prepared with brine III at $10 \%$ and $20 \%$ salinity. The brine composition and salinities were chosen to resemble that of Saudi formation brine. Figure 6 plots the obtained results indicating exponential IFT decline with the increase of IL concentration. More IFT reduction was noticed with increasing brine salinity and that can be attributed to the higher salt content that can alter the distribution of ionic liquids molecules on crude oil-brine interfacial surface [9]. Critical micelle concentrations were determined around $250 \mathrm{ppm}$ for both salinities with an IFT of $1.65 \mathrm{mN} / \mathrm{m}$ for the $20 \%$ salinity compared to $3.36 \mathrm{mN} / \mathrm{m}$ for $10 \%$ salinity. The obtained results prove that Ammoeng 102 possesses high capability to lower surface tensions and this can be related to its cationic nature with positive charges that are neutralized by the brine negatively charged ions leading to easier accumulation of IL molecules at the oil-brine interface, causing more IFT reduction.

Ammoeng 102 solution at $500 \mathrm{ppm}$ concentration was chosen for the later tests and IFT of crude oil-Ammoeng 102 solution diluted in $10 \%$ brine salinity was measured at various pressures and temperatures. Figures 7 and 8 present the results obtained indicating a slight IFT decreases with increasing temperature and slight increase with increasing pressure. The IFT trends obtained agrees with that presented by previous investigators in their work with conventional surfactants $[10,11]$. Similar trends are expected for Ammoeng 102 diluted in $20 \%$ brine salinity but with lower IFT values as proved previously. The thermal stability and high salinity tolerance prove that Ammoeng 102 is a good candidate for the EOR process in harsh reservoir conditions such as those characterizing Saudi reservoir.

\section{Flooding process}

Two flooding runs were conducted to investigate the efficiency of Ammoeng 102 as enhanced oil recovery chemical. Brine III at 10\% and $20 \%$ salinity and Saudi medium crude oil were used as aqueous and oleic phases respectively. The ionic solution was prepared by diluting 500 ppm of Ammoeng 102 in previous aqueous phase. First run was conducted by flooding core sample with $10 \%$ brine salinity in secondary flooding mode followed by the tertiary flooding of ionic solution at the same salinity. The second run was similar to the first one in scenario but at $20 \%$ salinity. Figure 9 presents the recovery and pressure drop outcomes of the flooding experiments indicating the superiority of $10 \%$ salinity secondary brine flooding with an additional recovery of $10 \%$ Original Oil in Place (OOIP). This finding agrees well with the findings obtained by previous investigators on the efficiency of low salinity flooding [12-14]. Low Salinity fluid promote desorption of $\mathrm{Ca}^{2+}$ from the clay surface which consequently creates a local increase in $\mathrm{pH}$ close to the brine-clay interface. A fast reaction between $\mathrm{OH}$ and the absorbed acidic and protonated basic material will cause desorption of organic material from the clay surface, and as the results the improves rock water wetness and hence enhance the oil recovery. Tertiary flooding of high salinity ionic solutions seems more effective providing additional recovery of $4.5 \%$ OOIP compared to 3 OOIP for low salinity solution flooding. These values correspond to $8 \%$ and $5 \%$ Residual Oil in Place (ROIP) for high and low salinity ionic solution flooding respectively. This can be attributed to the effectiveness of high salinity ionic solution in lowering the interfacial tension and altering rock wettability $[15,16]$. 
Citation: Bin-Dahbag MS, Quraishi AAAI, Benzagouta MS, Kinawy MM, Nashef IMAI, et al. (2014) Experimental Study of Use of lonic Liquids in Enhanced Oil Recovery. J Pet Environ Biotechnol 4: 165. doi:10.4172/2157-7463.1000165

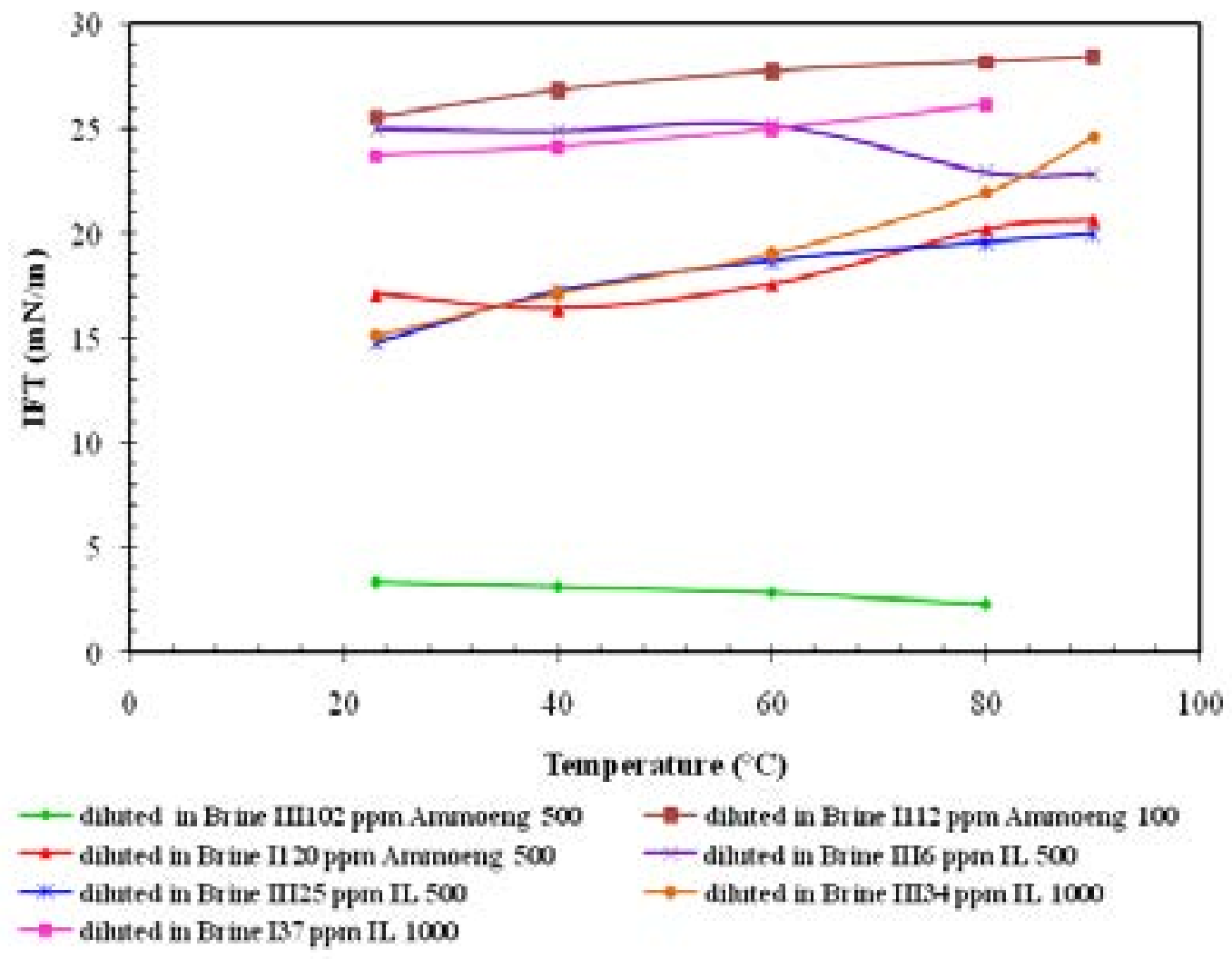

Figure 5: IFT Measurements of lonic Liquids Diluted in Different Concentrations ofBrinesI and III at $10 \%$ (w/w) Salinity.

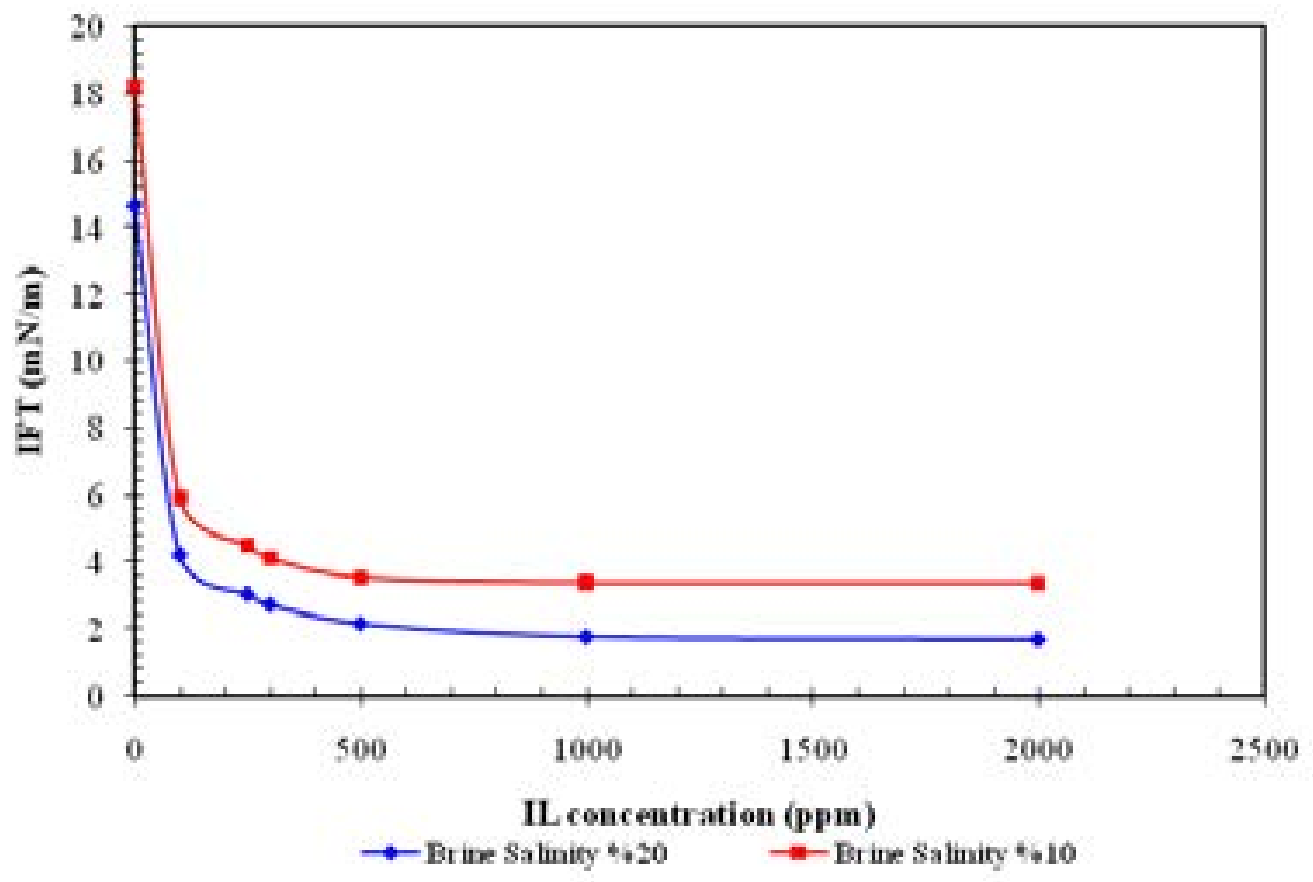

Figure 6: IFT of Ammoeng 102 Solution-Crude Oil at Different Concentrations and Two Brine Salinities. 


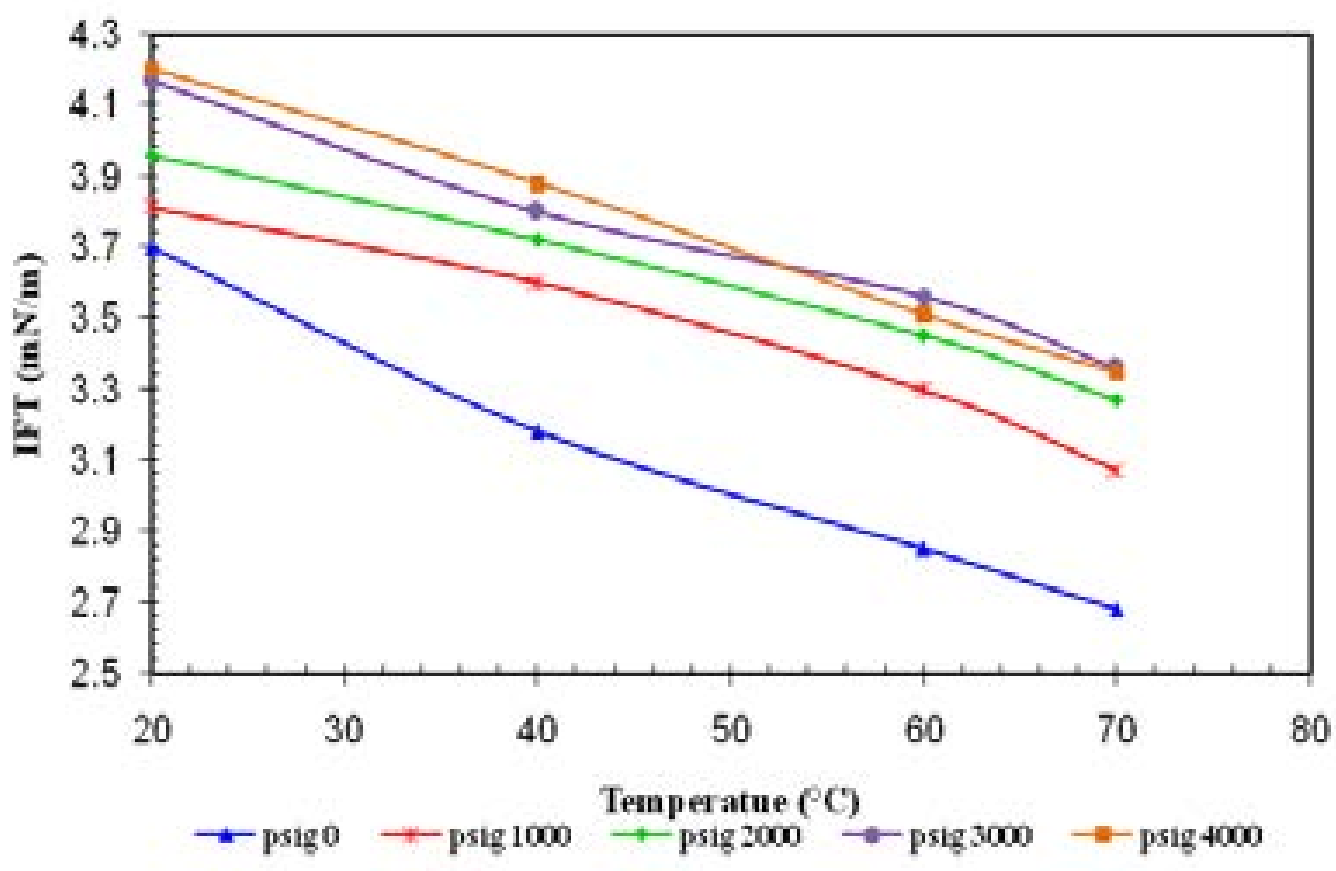

Figure 7: Effect of Temperature on 500 ppm Ammoeng 102 Solution-Crude Oil IFT.

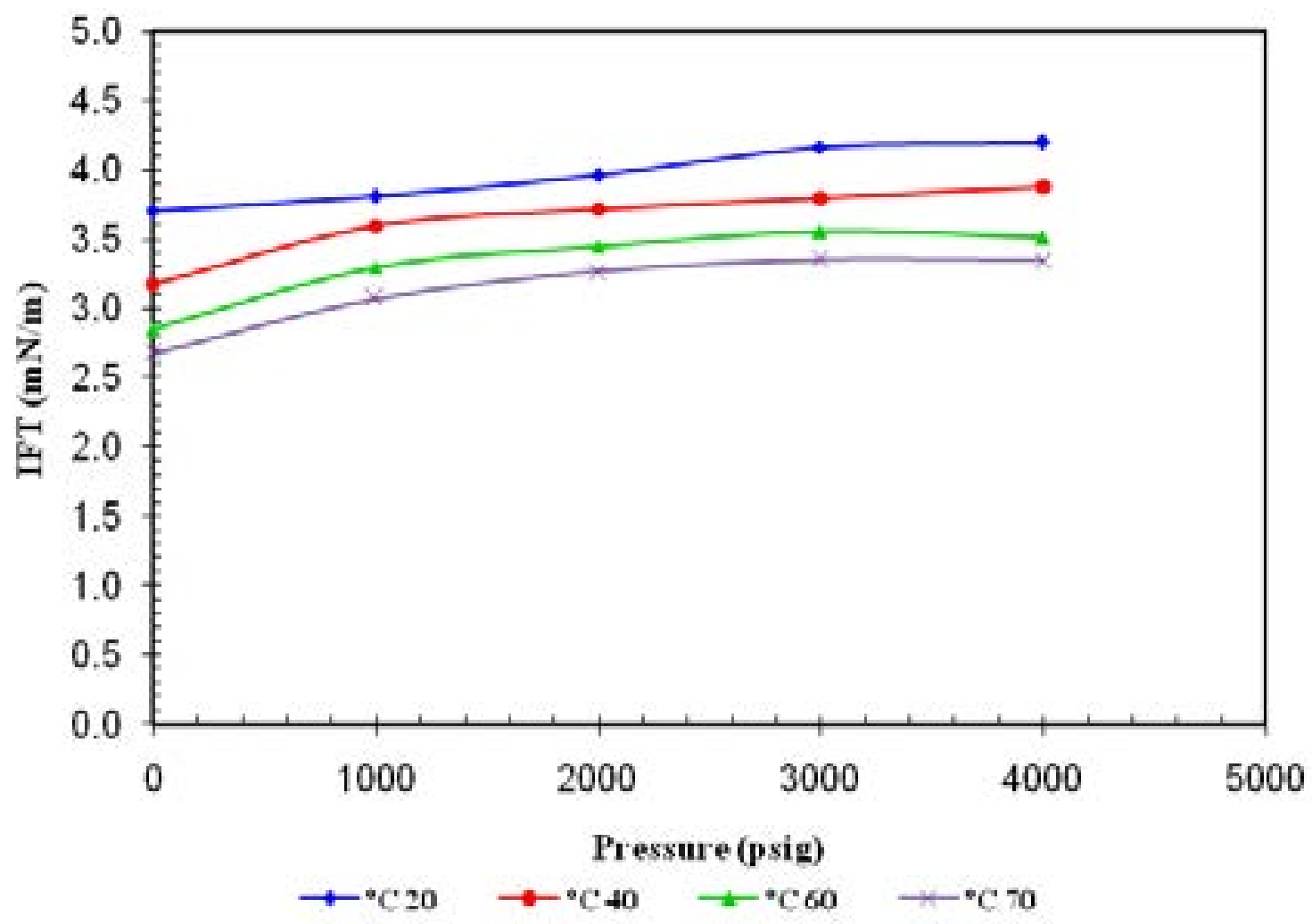

Figure 8: Effect of Pressure on 500 ppm Ammoeng 102 Solution-Crude Oil IFT. 
Citation: Bin-Dahbag MS, Quraishi AAAI, Benzagouta MS, Kinawy MM, Nashef IMAI, et al. (2014) Experimental Study of Use of lonic Liquids in Enhanced Oil Recovery. J Pet Environ Biotechnol 4: 165. doi:10.4172/2157-7463.1000165

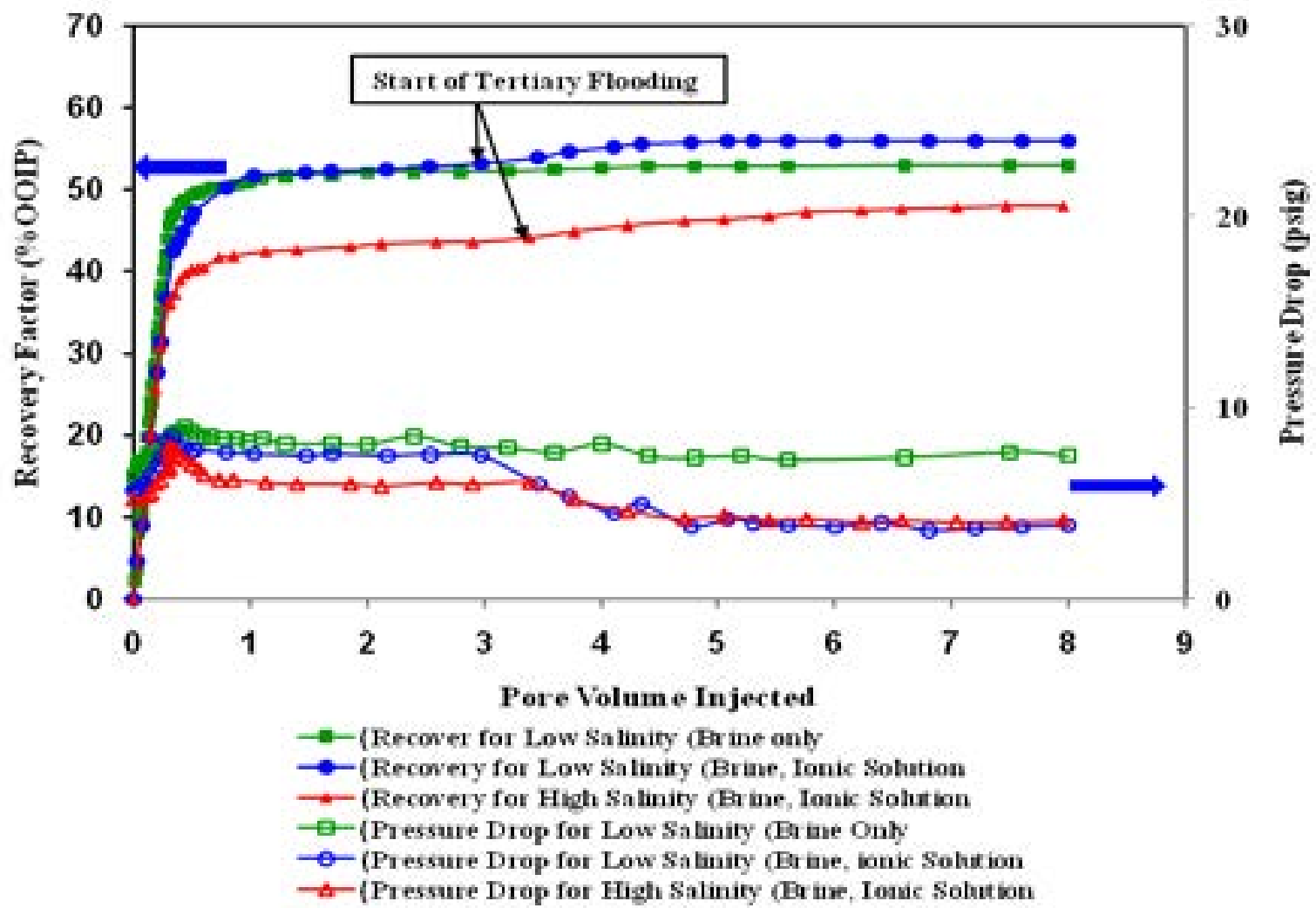

Figure 9: Recovery and Pressure Drop Curves of High and Low SalinitiesFlooding.

To check the reproducibility of our work, third run was conducted with $10 \%$ brine in secondary flooding mode on a fresh Berea core sample from the same block. The recovery was compared to that obtained previously in secondary flooding portion of run 1. Recovery curves plotted in Figure 9 was closely identical to that obtained in the first run indicating that salinity variation is the sole effect on flooding results.

The trend of pressure drop for all runs is presented in Figure 9. There exists a small difference in pressure during the secondary mode of runs 1 and 2 with higher pressure for low salinity secondary flooding (10\% brine flooding). This difference diminishes as we start the tertiary flooding with ionic solutions with decreasing trend for both salinities. The slight drop in pressure is attributed to the lower IFT values between displacing and displaced phases. Degree of salinity has minor effect on IFT as seen on Figure 6, therefore, pressure profiles during tertiary flooding is overlapped.

\section{Conclusion}

This study aimed at investigating the efficiency of ILs for chemical EOR. The work started by screening several ILs based on the solubility in brines, thermal stability and ability to significantly reduce the oleicaqueous phases IFT. Based on the screening process, Ammoeng 102 was the favorite IL. Further investigation of IFT between Ammoeng 102 diluted in brine III at $10 \%$ and $20 \%(\mathrm{w} / \mathrm{w})$ salinity and medium Saudi crude oil was conducted. IFT measurement for different IL concentrations at $2000 \mathrm{psig}$ and $60 \mathrm{oC}$ indicates IFT values exponentially decrease with increasing IL concentration. The CMC value for both solution salinities was $250 \mathrm{ppm}$ with lower IFT values for high salinity ionic solutions. Ammoeng 102 solution- crude oil IFT was insignificantly affected by temperature and pressures within the ranges investigated.

Two tertiary flooding runs were conducted on Berea sandstone samples using $500 \mathrm{ppm}$ of Ammoeng 102 diluted in Brine III at 10\% and $20 \%$ salinity at reservoir condition. The obtained results indicated that flooding with $10 \%$ brine salinity is more efficient than $20 \%$ in secondary mode, while the opposite state is taking place in tertiary flooding by the use of ionic solutions. Therefore, we suggest starting with low salinity brine secondary flooding followed by high salinity ionic solution for optimum recovery.

\section{Acknowledgments}

The authors express their sincere thanks and appreciations to the Department of Petroleum and Natural Gas Engineering in King Saud University and the oil and gas Research Institute at King Abdulaziz City for Sciences and Technology (KACST, Riyadh, KSA).

\section{References}

1. Domanska $U$ (2005) Solubilities and thermophysical properties of ionic liquids Pure Appl Chem 77: 543-557.

2. Simoni LD, Lin Y, Brennecke JF, Stadtherr MA (2008) Modeling LiquidLiquid Equilibrium of Ionic Liquid Systems with NRTL, Electrolyte-NRTL, and UNIQUAC. Ind Eng Chem Res 47: 256-272.

3. Johnson KE (2007) What's an Ionic Liquid? Interface-Electrochemical Society 16: 38-41. 
Citation: Bin-Dahbag MS, Quraishi AAAl, Benzagouta MS, Kinawy MM, Nashef IMAI, et al. (2014) Experimental Study of Use of lonic Liquids in Enhanced Oil Recovery. J Pet Environ Biotechnol 4: 165. doi:10.4172/2157-7463.1000165

Page 7 of 7

4. Bermúdez MD, Jiménez AE, Sanes J, Carrión FJ (2009) lonic liquids as advanced lubricant fluids. Molecules 14: 2888-2908.

5. Murillo H, Jose A, Aburto J (2011) Current Knowledge and Potential Applications of Ionic Liquids in The Petroleum Industry. Ionic Liquids: Applications and Perspectives 18: 439-458.

6. Rodríguez H, Arce A, Soto A (2012) Liquid-liquid interfacial tension of equilibrated mixtures of ionic liquids and hydrocarbons. Science China Chemistry 55: 1519-1524.

7. Fröba AP, Kremer H, Leipertz A (2008) Density, refractive index, interfacial tension, and viscosity of ionic liquids [EMIM][EtSO4], [EMIM][NTf2], [EMIM] $[\mathrm{N}(\mathrm{CN}) 2]$, and [OMA][NTf2] in dependence on temperature at atmospheric pressure. J Phys Chem B 112: 12420-12430.

8. Yan Y, Qiwei Y, Huabin X, Baogen S, Qilong R (2012) Surface/Interfacial Properties and Structures of Ionic Liquids. Progress in Chemistry 24: 659-673.

9. Bai JM, Fan WY, Nan GZ, Li SP, Yu BS (2010) Influence of Interaction between Heavy Oil Components and Petroleum Sulfonate on the Oil-Water Interfacial Tension. J Disper Sci Technol 31: 551-556.

10. Al-Sahhaf T, Elkamel A, Ahmed AS, Khan AR (2007) The Influence of
Temperature, Pressure, Salinity, and Surfactant Concentration on the Interfacial Tension of the N-Octane-Water System. Chem Eng Commun 192: 667-684.

11. Amir B, Philip B (1990) The Influence of Temperature and Surfactan Concentration on Interfacial Tension of Saline Water and Hydrocarbon Systems in Relation to Enhanced Oil Recovery by Chemical Flooding. Society of Petroleum Engineers.

12. Yousef AA, Al-Saleh S, Al-Kaabi A, Al-Jawfi M, Aramco S (2010) Laboratory Investigation of Novel Oil Recovery Method for Carbonate Reservoirs. Society of Petroleum Engineers.

13. Yousef AA, Al-Saleh S, Al-Kaabi A, Al-Jawfi M, Aramco S (2011) Laboratory Investigation of the Impact of Injection-Water Salinity and lonic Content on Oil Recovery From Carbonate Reservoirs. SPE Reserv Eval Eng 14: 578-593.

14. Tang GQ, Morrow NR (1997) Salinity, Temperature, Oil Composition, and Oil Recovery by Waterflooding. SPE Reservoir Eng 12: 269-276.

15. Wu S, Firoozabadi A (2009) Effect of Salinity on Wettability Alteration of Porous Media From Liquid Wetting to Intermediate Gas Wetting. Society of Petroleum Engineers.

16. Wu S, Firoozabadi A (2010) Effect of Salinity on Wettability Alteration to Intermediate Gas-Wetting. SPE Reserv Eval Eng 13: 228-245. 